\title{
THE FUTURE OF CHOICE OF LAW FOR TORTS: WHAT PRINCIPLES SHOULD BE PREFERRED?*
}

\author{
Russell J. Weintraub $\dagger$
}

INTRODUCTION

The tide of change in the conflict of laws is still rising. To date the courts of twenty-six states plus the District of Columbia and Puerto Rico have displaced the place-of-wrong rule as the sole choice-of-law rule for torts. ${ }^{1}$ The

\footnotetext{
* The reference is to David Cavers' "principles of preference," D. Cavers, ThE Choiceof-Law Process, chs. V-VIII (1965).

$\dagger$ Marrs McLean Professor of Law, University of Texas School of Law, Austin, Texas; author, Commentary on the Conflict of Laws (1971); co-author (with E. Scoles), Cases and Materials on Conflict of Laws (2d ed. 1972). This article will appear as part of the Torts chapter in the forthcoming second edition of COMMENTARY ON THE CoNflict of Laws.

1. Armstrong v. Armstrong, 441 P.2d 699 (Alas. 1968); Schwartz v. Schwartz, 103 Ariz. 562, 447 P.2d 254 (1968); Wallis v. Mrs. Smith's Pie Co., 550 S.W.2d 453 (Ark. 1977); Reich v. Purcell, 67 Cal. 2d 551, 432 P.2d 727, 63 Cal. Rptr. 31 (1967); First Nat'l Bank in Fort Collins v. Rostek, 182 Colo. 437, 514 P.2d 314 (1973); Williams v. Rawlings Truck Line, Inc., 357 F.2d 581 (D.C. Cir. 1965); Wartell v. Formusa, 34 Ill. 2d 57, 213 N.E.2d 544 (1966); Witherspoon v. Salm, 142 Ind. App. 655, 237 N.E.2d 116 (1968), rev'd on other grounds, 251 Ind. 575, 243 N.E.2d 876 (1969); Fabricius v. Horgen, 257 lowa 268, 132 N.W.2d 410 (1965); Wessling v. Paris, 417 S.W.2d 259 (Ky. 1967); Jagers v. Royal Indemnity Co., 276 So.2d 309 (La. 1973); Beaulieu v. Beaulieu, 265 A.2d 610 (Me. 1970); Pevoski v. Pevoski, 358 N.E.2d 416 (Mass. 1976); Kopp v. Rechtzigel, 273 Minn. 441, 141 N.W.2d 526 (1966); Mitchell v. Craft, 211 So.2d 509 (Miss. 1968); Kennedy v. Dixon, 439 S.W.2d 173 (Mo. 1969); Thompson v. Thompson, 105 N.H. 86, 193 A.2d 439 (1963); Mellk v. Sarahson, 49 N.J. 226, 229 A.2d 625 (1967); Babcock v. Jackson, 12 N.Y.2d 473, 240 N.Y.S.2d 743, 191 N.E.2d 279 (1963); Issendorf v. Olson, 194 N.W.2d 750 (N.D. 1972); Fox v. Morrison Motor Freight, Inc, 25 Ohio St. 2d 193, 267 N.E.2d 405, cert. denied, 403 U.S 931 (1971); Brickner v. Gooden, 525 P.2d 632 (Okla. 1974); Casey v. Manson Constr. \& Eng'r Co., 247 Or. 274, 428 P.2d 898 (1967); Griffith v. United Air Lines, Inc., 416 Pa. I, 203 A.2d 796 (1964); Widow of Fornaris v. Am. Sur. Co., 93 P.R.R. 28 (1966); Woodward v. Stewart, 104 R.I. 290, 243 A.2d 917, cert. dism'd, 393 U.S. 957 (1968); Johnson v. Spider Staging Corp., 87 Wash. 2d 577, 555 P.2d 997 (1976); Wilcox v. Wilcox, 26 Wis. 2d 617, 133 N.W.2d 408 (1965). See also Tab Constr. Co. v. Eighth Judicial Dist. Ct., 83 Nev. 364, 432 P.2d 90 (1967) (Nevada workmen's compensation act applies to Arizona employee of Arizona corporation injured in Nevada, citing, inter alia, Wilcox v. Wilcox, 26 Wis. 2d 617, 133 N.W.2d 408 (1965), refusing to apply the guest statute of the place of injury to a Wisconsin host and guest); LeBlanc v. Stuart, 342 F. Supp. 773 (D. Vt. 1972) (predicts Vermont would not apply the law of the place of injury to determine marital immunity).

Ten states have elected to retain the place-of-wrong rule rather than adopt a new approach. Menczer v. Menczer, 160 Conn. 563, 280 A.2d 875 (1971) (applies the law of the place of injury to prevent a Connecticut wife from suing a Connecticut husband and refuses to apply retroactively a statute [Conn. G. Stat. $\$ 52-572 d$ (Supp. 1977)] that requires application of Connecticut
} 
main thrust of the tide, though with many currents and eddies, is the insight that if, in the light of the law-fact pattern of the case at bar, only one state is likely to have to live with the long-range social consequences of applying one competing rule rather than another, it is that state's rule that should be applied.

Torts conflicts problems are not, however, always so easily solved. The purposes underlying the competing rules, what social evil they strive to ameliorate or what good encourage, may be difficult to discern with sufficient assurance to map the proper territorial scope of those purposes. Moreover, even if the policies and their legitimate reach are known, not one, but two or perhaps more states may be seen to have a rational, not officious, claim to the application of their own rules in furtherance of their own goals. How are these more difficult conflicts problems to be solved? It is to this question that courts and scholars are addressing themselves. In this article I will discuss the recent efforts of two great courts to resolve difficult choice-of-law problems -the "rules" approach taken by the New York Court of Appeals ${ }^{2}$ and the "comparative impairment" technique adopted by the California Supreme Court. $^{3}$ I will then, in the light of that discussion, offer my own "rules" for resolving torts conflicts problems. ${ }^{4}$

law between resident spouses); Friday v. Smoot, 211 A.2d 594 (Del. 1965), but see Williams v. Williams, 369 A.2d 669 (Del. 1976), applying Delaware law to determine whether children may sue mother for injuries caused in Maryland on the alternative grounds that Delaware public policy would not permit suit to proceed if Delaware law provided for immunity and that REStATEMENT (SECOND) Conflict of LAws $\$ 169(2)$ (1971) makes the law of the parties' domicil applicable to intra-family immunity); Hopkins v. Lockheed Aircraft Corp., 201 So. 2d 743 (Fla. 1967); McDaniel v. Sinn, 194 Kan. 625, 400 P.2d 1018 (1965); White v. King, 244 Md. 348, 223 A.2d 763 (1966); Abendschein v. Farrell, 382 Mich. 510 , 170 N.W.2d 137 (1969); Henry v. Henry, 291 N.C. 156, 229 S.E.2d 158 (1976) (permits suit under North Carolina law between Pennsylvania spouses when accident in North Carolina and refuses to extend a statute [N.C. Gen. Stat. \$ 52-5.1 (Supp. 1976)] directing application of North Carolina law between North Carolina spouses for injuries caused in other states); Oshiek v. Oshiek, 244 S.C. 249, 136 S.E.2d 303 (1964); Heidemann v. Rohl, 86 S.D. 250,194 N.W.2d 164 (1972); Winters v. Maxey, 481 S.W.2d 755 (Tenn. 1972). See also Chase v. Greyhound Lines, Inc., 195 S.E.2d 810 (W. Va. 1973), overruled on other grounds, Lee v. Comer, 224 S.E.2d 721 (W. Va. 1976), (stating, without discussing new approaches, that the law of the place of wrong applies to tort actions unless contrary to the public policy of the forum and that it is against West Virginia public policy for a parent to sue a child, but not for one sibling to sue another); Marmon v. Mustang Aviation, Inc., 430 S.W.2d 182 (Tex. 1968) (refuses to apply Texas wrongful death act to Colorado plane crash on ground that legislature, by reenacting statute without amendment, has acceded to Court's past constructions of the act as not applicable to fatal injuries inflicted out of Texas. The relevant statutes have now been amended to permit their application to fatal injuries caused elsewhere when the courts think appropriate [Tex. Rev. Civ. Stat. Arts. 4671, 4678 (Supp. 1976-77)]).

2. Neumeier v. Kuehner, 31 N.Y.2d 121,335 N.Y.S.2d 64, 286 N.E.2d 454 (1972).

3. Bernhard v. Harrah's Club, 16 Cal. 3d 313, 546 P.2d 719, 128 Cal. Rptr. 215, cert. denied, 429 U.S. 859 (1976).

4. I have previously assayed this task. R. Weintraub, Commentary on the Conflict of Laws 209 (1971). The rules proffered here are substantially different in form from my first attempt. 
I

New York's Return to a “Rules” ApProach

\section{A. The Rules}

Since 1963, the New York Court of Appeals has decided six major cases ${ }^{5}$ centering on the question of whether a guest's right to recover against his New York host driver is to be determined by the ordinary negligence standard of New York or by a heightened degree of wrongdoing, such as "gross negligence," required for recovery by a "guest statute" of another jurisdiction. The struggle of the Court with these cases has been awesome to behold -dissents, shifting doctrine, results not easily reconcilable. In short, a law professor's delight but a practitioner's and judge's nightmare. It is quite understandable, then, that weary from this struggle, a majority of the Court felt that the time had come to inject a measure of predictability into New York conflicts doctrine that had been absent since New York discarded the placeof-wrong rule.

Neumeier $v$. Kuehner ${ }^{6}$ provided the setting for the announcement of the new rules for guest-statute cases. In Neumeier, a New Yorker was driving his automobile, registered and insured in New York, between two points in Ontario with an Ontario friend as his guest passenger. On this trip the car collided with a train. Both the New York host and his Ontario guest were killed. The personal representative of the deceased Canadian brought a wrongful death action in New York against the estate of the New York host and against the railroad. An Ontario statute made a driver, other than one in the business of carrying passengers for compensation, liable for injuries to his passengers only if these injuries resulted from the driver's gross negligence. The defendants $^{7}$ pleaded this Ontario statute as a defense and the New York Court of Appeals held that the Ontario statute was applicable. Chief Judge Fuld, in his majority opinion, set forth three rules $^{8}$ that he indicated would

5. Babcock v. Jackson, 12 N.Y.2d 473, 191 N.E.2d 279, 240 N.Y.S.2d 743 (1963); Dym v. Gordon, 16 N.Y.2d 120, 209 N.E.2d 792, 262 N.Y.S.2d 463 (1965); Macey v. Rozbicki, 18 N.Y.2d 289, 221 N.E.2d 380, 274 N.Y.S.2d 591 (1966); Tooker v. Lopez, 24 N.Y.2d 569, 249 N.E.2d 394, 301 N.Y.S.2d 519 (1969); Neumeier v. Kuehner, 31 N.Y.2d 121, 286 N.E.2d 454, 335 N.Y.S.2d 64 (1972); Towley v. King Arthur Rings, Inc., 40 N.Y.2d 129, 351 N.E.2d 728,386 N.Y.S.2d 80 (1976).

6. 31 N.Y.2d 121, 286 N.E.2d 454, 335 N.Y.S.2d 64 (1972).

7. The railroad urged application of the Ontario "gross negligence" standard to determine the New York driver's liability because if it applied, the railroad would be insulated from that portion of the damages attributable to the fault of the New York driver. Ont. REv. Stat. c. 296, $\S 2(2)(1970)$.

8. 31 N.Y.2d at 128,286 N.E. $2 d$ at $457-58,335$ N.Y.S.2d at 70 :

1. When the guest-passenger and the host-driver are domiciled in the same state, and the car is there registered, the law of that state should control and determine the standard of care which the host owes to his guest.

2. When the driver's conduct occurred in the state of his domicile and that state does not cast him in liability for that conduct, he should not be held liable by reason of the fact that liability would be imposed upon him under the tort law of the state of the 
henceforth be used in resolving conflicts cases involving the liability of a host driver to his guest. These rules were quoted from Judge Fuld's concurring opinion in a prior case. ${ }^{9}$

Rule 1 states that if the host and guest are domiciled in the same state and the car is also registered there, the law of that state determines the standard of care that the host owes the guest.

Rule 2 focuses on the situation in which the host resides in a state that has a guest statute and the guest resides in a state that does not have a guest statute. Under these circumstances, if the host's conduct occurs in the host's state then the host should not be liable under the law of the guest's state, but if the host injures the guest in the guest's state, the driver should not "in the absence of special circumstances" be entitled to the protection of the guest statute of his own state. ${ }^{10}$

Rule 3 is addressed to other situations when the host and the guest are domiciled in different states. In these circumstances the Court will "normally" apply the law of the state where the accident occurred unless applying a different rule "will advance the relevant substantive law purposes without impairing the smooth working of the multi-state system or producing great uncertainty for litigants." 11

The Court held that Neumeier fell under Rule 3, that the exception to normal application of the law of the place of accident was not applicable, and that therefore the Canadian statute was applicable. ${ }^{12}$

\section{B. Examination of the Neumeier Rules}

1. Rule 1: Host, guest, and car from same state.

The most obvious question concerning this rule is why, as between host and guest, ${ }^{13}$ it makes any difference where the car is registered. Suppose two

victim's domicile. Conversely, when the guest was injured in the state of his own domicile and its law permits recovery, the driver who has come into that state should not-in the absence of special circumstances-be permitced to interpose the law of his state as a defense.

3. In other situations, when the passenger and the driver are domiciled in different states, the rule is necessarily less categorical. Normally, the applicable rule of decision will be that of the state where the accident occurred but not if it can be shown that displacing that normally applicable rule will advance the relevant substantive law purposes without impairing the smooth working of the multi-state system or producing great uncertainty for litigants.

9. Tooker v. Lopez, 24 N.Y.2d 569, 585, 249 N.E.2d 394, 404, 301 N.Y.S.2d 519, 532-33 (1969).

10. 31 N.Y.2d at 128,286 N.E. $2 d$ at 458,335 N.Y.S. $2 d$ at 70.

11. Id.

12. On remand, plaintiff was granted leave to amend the complaint to allege gross negligence and defendant Kuehner's motion to dismiss on forum non conveniens grounds was denied. Neumeier v. Kuehner, 43 App. Div. 2d 109, 349 N.Y.S.2d 866 (1973).

13. For a holding that a company renting an automobile to the host may not, when charged with negligence and breach of warranty, invoke the guest statute of the place of accident and 
New York friends fly on vacation to a state with a guest statute. There one of them rents a car and the other is injured while a passenger. What possible reason could there be for applying that state's guest statute when guest sues host back in New York? Perhaps insurance rates in the vacation state might be affected if the only liability insurance in force is that provided by the rental company. But is this "interest" of the place of accident in protecting insurance rates from the pressures of recoveries under suspiciously collusive circumstances sufficient to make New York abandon its quest for adequate compensation to a New York guest injured by a negligent New York host? Even this reason for applying the law of the place of accident fades if, as is likely, the host elects not to pay the rental company for liability insurance and is covered instead by his New York policy. ${ }^{14}$ It should be noted that if registry of the car is in fact a major requirement of Rule 1 and not just an unfortunate and unnecessary afterthought, ${ }^{15}$ none of the Court's rules covers the hypothetical of the New Yorkers on vacation.

Rule 1 will work best when a New York guest is injured in a guest statute state. But if parties from a guest statute state crash in New York, should New York invariably protect the host under the statute of his home state? ${ }^{16}$ Suppose the host collides with a car driven by a New Yorker. The guest sues the New Yorker and the New Yorker impleads the host for contribution. If, as is widely supposed, ${ }^{17}$ the New Yorker cannot obtain contribution unless the host is liable to the guest, should New York abandon its contribution policy ${ }^{18}$ in favor of the paradoxical purposes of preventing ingratitude and collusion un-

registry, see Pahmer v. Hertz Corp., 36 App. Div. 2d 252, 319 N.Y.S.2d 949 (1971), aff'd on other grounds, 32 N.Y.2d 119,296 N.E.2d 243, 343 N.Y.S.2d 341 (1973).

14. The premiums for liability insurance in an amount that complies with each state's financial responsibility law reflect the number and cost of accidents chargeable to policies covering drivers whose cars are principally garaged in that state and within a particular rating territory in the state. See McNamara, Automobile Liability Insurance Rates, 35 Ins. Counsel J. 398, 401, 403-06 (1968); Stern, Ratemaking Procedures for Automobile Liability Insurance, 52 Proc. Cas. Actuarial Soc'y 139, 155, 176-77, 183 (1965).

15. For a holding that despite its mention in Neumeier, the place of registry lacks significance, see Gyory v. Radgowski, 82 Misc. 2d 553, 369 N.Y.S.2d 583 (Sup. Ct. 1974).

16. The New York intermediate appellate courts are split on this question. See, e.g., Rye v. Kolter, 39 App. Div. 2d 821 , 333 N.Y.S.2d 96 (1972) (apply New York law); Arbuthnot v. Allbright, 35 App. Div. 2d 315,316 N.Y.S.2d 391 (1970) (apply Ontario law).

17. See, e.g., Shonka v. Campbell, 260 Iowa 1178, 152 N.W.2d 242 (1967) (citing many cases in accord); Uniform Contribution Among Tortfeasors Act \$§ 1, 2(1) (1939 version). Contribution may be obtained in Pennsylvania even though the other tortfeasor is insulated from liability. Restifo v. McDonald, 426 Pa. 5, 230 A.2d 199 (1967) (intrafamily immunity).

For a suggestion that this conflict be solved by applying the guest statute to bar any claim by the guest against the host, but permitting the driver of the other car to obtain indemnity from the host to the extent that the other driver pays more than half the verdict, see Weintraub, Beyond Dépeşage: $A$ "New Rule" Approach to Choice of Law in Consumer Credit Transactions and a Critique of the Territorial Application of the Uniform Consumer Credit Code, 25 CASE W. Res. L. Rev. 16, 28 (1974).

18. Holding that New York would apply New York law to all defendants in this situation, see Saleem v. Tamm, 67 Misc. 2d 335, 323 N.Y.S.2d 764 (Sup. Ct. 1971). 
derlying a statute that is fast becoming extinct? ${ }^{19}$ Or assume that the seriously injured guest is cared for in New York, running up huge medical bills that are unpaid and will remain unpaid unless the host's liability insurance can be tapped. ${ }^{20}$

2. Rule 2: Host's state has statute, guest's state does not, and crash is in one of these states.

Applying the law of the place of accident produces a result that at least is defensible in most circumstances; but suppose that the trip during which the accident occurs is one that has touched or is intended to touch on both states. Do we really want the result to depend on which side of the state line the car happened to be on when the guest was injured? ${ }^{21}$ Would this case fall under the cryptic "special circumstances" exception in the rule? Alas, that exception is addressed only to the proposition that the driver will not always be subjected to the ordinary negligence rule of the guest's state when he injures the guest there. Perhaps in our hypothetical involving driving in both states we could interpret the first words of the rule- "when the driver's conduct occurred in the state of his domicile"-to mean "all of his conduct, actual and intended, during the events preceding the injury".

3. Rule 3: Apply the law of the place of accident in other situations in which host and guest are domiciled in different states.

The Court holds that Neumeier does not fall within the vague exception articulated at the end of the rule. This result raises the question when the exception will apply and, despite Chief Judge Fuld's disclaimer, invites the accusation of invidious discrimination against guests who are unlucky enough not to live in New York. ${ }^{22}$

19. Eight states have declared their guest statutes unconstitutional since 1973. See authority collected in Sidle v. Majors, 429 U.S. 945,946 n.2 (1976). In addition, many guest statutes have been repealed or narrowed. See, e.g., 1975 Colo. Sess. Laws p. 1568, \& 1 (repeal); 1972 Fla. L. c. $72-1, \S 1$ (repeal); 1974 Kan. Sess. Laws c. 32, § 1 (repeal) (also one of states in which guest statute had been declared unconstitutional); TEx. Crv. STAT. Art. 6701(b) (1977) (limited to guests within second degree of consanguinity or affinity); $1970 \mathrm{Vt}$. Acts No. $194 \$ 1$ (repeal); VA. CoDE \$ 8-646.1 (Supp. 1976) (in effect repeals-changes "gross negligence" to "negligent"). See also MASS. Gen. LawS c. 231, § 85L (Supp. 1977-78) abolishing the judicially-created gross negligence requirement of Massaletti v. Fitzroy, 228 Mass. 487, 118 N.E. 168 (1917).

20. See Bray v. Cox, 39 App. Div. 2d 299, 333 N.Y.S.2d 783 (1972), appeal dism'd, 33 N.Y.2d 789,305 N.E.2d 775, 350 N.Y.S.2d 653 (1973) (New York's interests in protecting medical creditors and in assuring that injured nonresidents do not become public charges justifies application of New York law rather than Ontario guest statute to Ontario host and guest); $c f$. Milkovich v. Saari, 295 Minn. 155, 203 N.W.2d 408 (1973) (likelihood of medical costs justifies application of law of place of crash even though in case at bar the bills have been paid).

21. But see Cipolla v. Shaposka, 439 Pa. 563, 267 A.2d 854 (1970) (apply Delaware guest statute when Delaware host, Pennsylvania guest, Pennsylvania destination, crash in Delaware; court disclaims considering the place of the accident as a "relevant contact").

22. See Trautman, Rule or Reason in Choice of Law: A Comment on Neumeier, 1 VT. L. REv. 1,18 (1976). 
If ever the exception of Rule 3 is to apply, it should be in the case in which host and guest come from different states, neither state has a guest statute, but the crash is in a guest statute state. ${ }^{23}$ In the first major guest statute case decided by the Court after Neumeier, however, Iowa guest met New York host while both were vacationing in Colorado. ${ }^{24}$ The Court applied the Colorado guest statute to a one-car $\mathrm{crash}^{25}$ in Colorado without even pausing to inquire whether Iowa had a guest statute ${ }^{26}$ or had one different in terms $^{27}$ or application ${ }^{28}$ from the Colorado statute. Nor did the Court note that the Colorado guest statute had been repealed after the accident but more than a year before its opinion. ${ }^{29}$

\section{The Rhode Island "Rules" Approach Contrasted}

The Court of Appeals' quest for conflicts rules is understandable. Given the complexity that is possible in the new conflicts analysis, a court may well wish to avoid treating every conflicts case as a new problem to be analyzed from scratch. ${ }^{30}$ The safest way to implement a rules approach is to wait until the court has decided a variety of cases focusing on the same choice-of-law problem. If the results of these cases can be succinctly and clearly summarized, ${ }^{31}$ this summary of the pattern of decided cases can provide "rules" to guide the court, lower courts, and attorneys. When, however, a rule articulated by a court purports to be broader than the pattern of already decided cases, this is a more hazardous undertaking. At the very least, the court should think through the fact patterns that are likely to occur in future cases and see whether in those situations it would desire the result dictated by the new rules.

This process of stating a rule to cover yet undecided fact situations and doing so in a manner that the court is reasonably sure will not prove embar-

23. See, e.g., Chila v. Owens, 348 F. Supp. 1207 (S.D.N.Y. 1972).

24. Towley v. King Arthur Rings, Inc., 40 N.Y.2d 129, 35l N.E.2d 728, 386 N.Y.S.2d 80 (1976).

25. This made the case more like Tooker v. Lopez, 24 N.Y.2d 569, 301 N.Y.S.2d 519, 249 N.E.2d 394 (1969) (New York host and guest, crash in Michigan, New York law applied) than Dym v. Gordon, 16 N.Y.2d 120, 262 N.Y.S.2d 463, 209 N.E.2d 792 (1965) (New York host and guest, crash in Colorado, Colorado law applied). I disapprove of the distinction between one-car and two-car crashes suggested by the reasoning of Dym.

26. It has. Iowa CoDE $\$ 321.494$ (Supp. 1977-78).

27. Colo. Rev. Stat. \& 42-9-101 (1963) (formerly $\$ 13-9-1$; now repealed, see note 29 infra): "willful and wanton disregard of the rights of others". IowA Code $\S 321.494$ (Supp. 1977-78): "reckless operation".

28. The Court did decide that, in the light of Colorado opinions applying the Colorado statute, it could not be said as a matter of law that the trial court erred in leaving the question of whether the host's conduct was "willful and wanton" to the jury. The Court remitted the case to the Appellate Division for a review of the facts. The Appellate Division had reversed the judgment against the driver and dismissed the complaint.

29. 1975 Colo. Sess. Laws, p. 1568 , $\$ 1$.

30. See Reese, Choice of Law: Rules or Approach, 57 Cornell L. Rev. 315, 322-23 (1972).

31. This is not true of the New York cases cited in note 5 supra. 
rassing in the future is very difficult, but as Labree $v$. Major ${ }^{32}$ decided by the Rhode Island Supreme Court, indicates, is not impossible for an able and imaginative court. Labree presented a fact pattern similar to that in Neumeier, was decided by a court embarking on a rules approach, but reached the opposite result.

In Labree, a Rhode Island driver was taking some Massachusetts friends between two points in Massachusetts. There was a collision with another car in Massachusetts and the guests were injured. At the time, under a Massachusetts judicially-created rule, ${ }^{33}$ a guest passenger could recover against his host driver only for gross negligence. Under Rhode Island law, there could be recovery for ordinary negligence. The Rhode Island Supreme Court held that the Rhode Island rule, favoring recovery, applied. The Court noted that this case would fall under the third rule in Neumeier, but rejected that rule. The Rhode Island judges viewed the third rule as a thinly-disguised place-ofwrong standard containing an exception so vague that it destroyed the certainty of application that a rules approach seeks. The Court created its own rule for guest statute cases in lieu of Judge Fuld's third rule: "where a driver is from a state which allows a passenger to recover for ordinary negligence, the plaintiff should recover, no matter what the law of his residence or the place of accident." ${ }^{4}$ The Court suggested that no other state could have a reasonable objection to the defendant's home state holding the defendant to a stricter standard of conduct even when he ventured abroad. This seems a defensible proposition and makes it unlikely that the Rhode Island Court will find its narrowly-drawn rule unworkable in unforeseen circumstances.

II

\section{Neumeier AND Labree AS "UNPROVIDED" CASES}

One of the difficulties with Neumeier and Labree is that they are "unprovided"35 or "no interest" cases. The classic "no interest" case is one in which the plaintiff's state has a law favorable to the defendant and the defendant's state has a law favorable to the plaintiff. The term "no interest" comes from the argument that neither state is interested in having its own law apply. The plaintiff's state has no interest in protecting the defendant who comes from another state and the defendant's state has no reason to give the plaintiff more compensation than he would get under the law of his own state.

Perhaps the best known of the no-interest cases is Hurtado v. Superior Court. $^{36}$ In Hurtado, a Mexican resident, while visiting California, was killed when the car in which he was a passenger collided with a parked car. A

32. 111 R.I. 657,306 A.2d 808 (1973).

33. Massaletti v. Fitzroy, 228 Mass. 487, 118 N.E. 168 (1917). Doctrine abolished by Mass.

Gen. Laws c. 231, § 85L (Supp. 1977-78).

34. 111 R.I. at $673,306 \mathrm{~A} .2 \mathrm{~d}$ at 818 .

35. See B. Currie, Selected Essays on the Conflict of Laws 152 (1963).

36. 11 Cal. 3d 574, 522 P.2d 666, 114 Cal. Rptr. 106 (1974). 
wrongful death action was brought against the driver of the car in which the decedent was a passenger and against the owner of the parked automobile. Both defendants were California residents. Under the law of the Mexican state in which the decedent was domiciled at the time of his death, a maximum recovery of just under $\$ 2,000$ was available. California placed no monetary limit on recovery. The California Supreme Court held that the California measure of recovery for wrongful death should apply.

Hurtado contains a factual distinction from both Neumeier and Labree-a distinction on which the California Supreme Court focused. In Hurtado, the California defendants performed their allegedly negligent acts in California. The Court saw deterrence of negligent conduct as one of the reasons for California's rule of full compensation for wrongful death. This deterrence policy was applicable when a California resident acted tortiously in California.

Is Hurtado's deterrence argument cogent? If a California driver does not drive carefully because of fear for his own safety, or for fear of the safety of his loved ones and friends who are passengers, or for fear of the sanctions of criminal law, is he likely to be made a more careful driver by the specter of California's unlimited recovery? Perhaps the effect of an accident on the cost and availability of liability insurance is some incentive for more prudent driving. ${ }^{37}$ There is very little empirical data that throws light upon the question of whether a combination of civil liability and insurance practices deters careless driving. ${ }^{38}$ If such a proposition ever is established, I for one would find it counterintuitive. ${ }^{39}$ In the meantime, I would prefer a more compelling

37. See Cramton, Driver Behavior and Legal Sanctions: A Study of Deterrence, 67 Mich. L. Rev. $421,445,453$ (1969); Trautman, supra note 22, at 5.

38. See Little, $A$ Theory and Empirical Study of What Deters Drinking Drivers, If, When and Why, 23 AD. L. Rev. 23, 50 (1970):

When asked to select which alternative they would mind less in a series of all possible pairings of four undesirable consequences, the drivers showed their preferences from least undesirable to most undesirable to be:

(1) A $\$ 250$ accident with no injuries (selected on $70 \%$ of 606 binary choices).

(2) An accident with minor personal injury (selected $56 \%$ ).

(3) A drunk driving arrest (selected 34\%).

(4) Loss of driving privileges for one year (selected $33 \%$ ).

39. I am admittedly on very shaky ground here. A distinguished court has referred to my doubts about the efficacy of deterrence in this context as the "naive product of wishful thinking." Hunker v. Royal Indem. Co., 57 Wis. 2d 588, 604 n.2, 204 N.W.2d 897, 905-06 n.2 (1973).

For cases permitting the plaintiff to recover under the law of the place of the crash, partly because of an interest in deterring negligent driving, see Gagne v. Berry, 112 N.H. 125, 290 A.2d 624 (1972) (New Hampshire law applied to permit Massachusetts guest to recover against Massachusetts host); Bray v. Cox, 39 App. Div. 2d 299, 333 N.Y.S.2d 783 (1972), appeal dism'd, 33 N.Y.2d 789, 305 N.E.2d 775, 350 N.Y.S.2d 653 (1973) (New York law applied to permit Ontario guest to sue Ontario host).

For commentators approving of a deterrence interest, see D. Cavers, supra note*, at 144; Horowitz, The Law of Choice of Law in California-A Restatement, 21 U.C.L.A. L. REv. 719, 757 (1974). But see Ratner, Choice of Law: Interest Analysis and Cost-Contribution, 47 S. CAL. L. REv. 817, 840 (1974) ("If automobile accident recovery policies did deter careless driving, narrower recov- 
argument to support the Hurtado result.

One tempting basis for resolving the "unprovided" case is to fall back upon the core legal concepts that are common to both jurisdictions. Both states have a general background of liability for wrongful conduct. The rule of the plaintiff's state limiting that liability is an exception to the general rule of liability-an exception that is not applicable if its sole purpose is to protect defendants resident in that state or in states with similar rules. If the exception is not applicable, the rule-liability-is and this is then the common result under the law of both states. ${ }^{40}$

The difficulty with this "common core" basis for resolving no-interest cases is that there is danger of begging the question by attaching one label rather than another. Why is it not just as accurate to say that the background rule is no liability for conduct unless there is a rule specifically imposing liability? ${ }^{41}$ This objection seems especially appropriate when addressed to liability for wrongful death in the light of the great differences in compensable losses and methods of computing damages that exist even between states of the United States. ${ }^{42}$ There are times when the "common core" concept may be especially attractive. For example, one could argue with some force that all states have a policy of validating wills and that if a state has a particular invalidating rule, which in the light of its underlying policies is not applicable to the law-fact pattern in litigation, the common policy of validation should prevail. But this kind of argument should be used with great caution to avoid illogical leaps to results that are desired for unarticulated reasons.

Another way of deciding the "unprovided" case is to re-examine the tentative conculsion that neither state has a policy that will be advanced by applying its law. By finding a deterrence policy, the court in Hurtado converted a "no interest" case into a "false conflict" in which California had an interest in imposing liability but the Mexican state had no interest whatever in preventing full liability. In the same manner, it would be possible to reanalyze both Neumeier and Labree and defend the result in each as the only sensible resolution of a false conflict. In Neumeier, the New York Court of Appeals suggested that although New York has no interest in giving an Ontario citizen recovery not available under Ontario law, Ontario certainly has an interest in seeing to it that its citizens behave graciously in Ontario and do not manifest their in-

ery by a small number of nonresidents from restrictive-recovery states would not significantly diminish the local deterrent effect.")

40. See Sedler, Interstate Accidents and the Unprovided for Case: Reflections on Neumeier v. Kuehner, 1 Hofstra L. Rev. 125, 138 (1973); $c f$. Baade, The Case of the Disinterested Two States: Neumeier v. Kuehner, 1 Hofstra L. Rev. 150, 167 (1973) (not a proper basis for decision in Neumeier so long as Ontario applies its guest statute to uninsured Ontario motorists).

41. See Milhollin, The Forum Preference in Choice of Law; Some Notes on Hurtado v. Superior Court, 10 U.S.F.L. Rev. 625, 646-47 (1976).

42. See S. Speiser, I Recovery for Wrongful Death cs. 3-8 (2d ed. 1975). 
gratitude by extracting compensation from hosts who are only ordinarily negligent. ${ }^{43}$ On the other hand, the Labree result could be defended on the basis of the "altruism" policy articulated in that opinion: a state has an interest in having its drivers bear the primary responsibility for distributing the cost of their injurious conduct no matter where this conduct occurs or who is injured by that conduct.

The question then becomes which of the policies articulated to resolve the "unprovided" cases, Neumeier, Labree, and Hurtado, is the most credible. I vote for Labree.44

43. 31 N.Y.2d 121, 125-26, 286 N.E.2d 454, 456, 335 N.Y.S.2d 64, 68. But see Baade, supra note 40 , at 156 ("the sole apparent legislative purpose of the Ontario guest statute . . is to protect insurance companies against claims which would necessitate an increase of motor vehicle insurance rates in Ontario.").

44. For holdings that defendant's state should make the benefits of its law available to nonresidents, see McCrossin v. Hicks Chevrolet, Inc., 248 A.2d 917 (D.C. App. 1969) (D.C. rule dispensing with privity requirement is for benefit of all who buy in the District, not just for residents); Frummer v. Hilton Hotels Int'l, Inc., 60 Misc. 2d 840, 304 N.Y.S.2d 335 (Sup. Ct. 1969) (England would not be so "parochial" as to claim it has no interest in compensating a New York plaintiff at the expense of an English defendant); Hepp v. Ireland, 66 Civ. 2128 (S.D.N.Y. 1970) (unreported, discussed in D. Cavers, Contemporany Conflicts Law in American Perspective, in 131 Collected Courses of the Hague Academy of Int'l L. 179 n.24 (1970 III), and excerpt from opinion quoted in Ausubel, Conflict of Laws Trends-Torts, 19 DePaul L. Rev. 684, 692 (1970) (the New York policy of financial responsibility for motorists extends to all people injured by the negligence of motorists reachable by the New York policy). See also Shapira, "Manna for the Entire World" or "Thou Shalt Love Thy Neighbor as Thyself"-Comment on Neumeier v. Kuehner, 1 Hofstra L. Rev. 168, 172 (1973); Note, Choice of Law in Tort Cases: Neumeier v. Kuehner, 37 ALB. L. REv. 173, 187 (1972); of. von Mehren, Special Substantive Rules for Multistate Problems: Their Role and Significance in Contemporary Choice of Law Methodology, 88 HARv. L. Rev. 347, 369 (1974) (Neumeier could be solved by giving plaintiff recovery for one-half of the damage).

For other cases in which the plaintiff was allowed to recover under the more favorable law of the defendant's state, see, e.g., Gravina v. Brunswick Corp., 338 F. Supp. 1 (D. R.I. 1972) (invasion of privacy, "better rule"); Decker v. Fox River Tractor Co., 324 F. Supp. 1089 (E.D. Wis. 1971 ) (products liability, "better rule"); Dworak v. Olson Constr. Co., 551 P.2d 198 (Colo. 1976) (effect on other defendant of covenant not to sue, forum preference in the absence of more contacts elsewhere); Bolgrean v. Stich, 293 Minn. 8, 196 N.W.2d 442 (1972) (guest statute; center of gravity, better law; plaintiff has since resumed former residence in defendant's state); Brown v. Market Development, Inc., 41 Ohio Misc. 57, 322 N.E.2d 367 (1974) (action by Ohio Attorney General, Ohio statute applies to deceptive and unconscionable practices directed at nonresidents); Erwin v. Thomas, 264 Ore. 454, 506 P.2d 494 (1973) (automobile accident, loss of consortium, forum preference); Johnson v. Spider Staging Corp. 87 Wash. 2d 577, 555 P.2d 997 (1976) (products liability, deterrence); of. In re Paris Air Crash, 399 F. Supp. 732 (C.D. Cal. 1975) (products liability, California law applied to California defendants to both increase and limit liability). But see Gordon v. Eastern Air Lines, 391 F. Supp. 31 (S.D.N.Y. 1975) (New York dependents of New Yorker killed in Florida crash limited to items compensable under New York wrongful death law); Heavner v. Uniroyal, Inc., 63 N.J. 130, 305 A.2d 412 (1973) (products liability, fact that defendant, a national company, is incorporated in New Jersey, is not enough to permit North Carolina resident to recover under New Jersey law); Cavers, Cipolla and Conflicts Justice, 9 Duquesne L. Rev. 360, 370 (1971) ("quixotic" to give guest benefit of law of host's state when relationship created and ended in guest's state); Ratner, supra note 39, at 836 (nonresidents who do not contribute to local taxes, prices, and insurance premiums should not benefit from local law more favorable than that in their home states); $c f$. Baade, supra note 40 , at 162 (although in 
III

Comparative Impairment in California

\section{A. Bernhard v. Harrah's Club}

The opposite of the "no interest" case is the "true conflict" in which each of two or more states would have its policy advanced by having its law, rather than the different rule of another state, applied to the case being decided. A recent California Supreme Court decision deals with the true conflict problem in a noteworthy manner.

In Bernhard v. Harrah's Club, ${ }^{45}$ a California plaintiff was injured when his motorcycle collided in California with an automobile driven by another California resident. The automobile driver had become intoxicated at a Nevada gambling establishment from which she was driving home. The Nevada club advertised in California and solicited the business of California residents. Under Nevada law, service of liquor to a drunk person does not render the server civilly liable for harm caused by the drunk. Under California law, service of intoxicating beverages to a person obviously intoxicated is regarded as a proximate cause of injury resulting from the drunk's conduct and the server is liable.

The California Supreme Court recognized that both Nevada and California were interested in having their own rules applied. Nevada wished to protect the bar owner from civil liability because that was Nevada's policy and the defendant was a Nevada corporation that served the beverages in Nevada. California wished to "prevent tavern keepers from selling alcoholic beverages to obviously intoxicated persons who are likely to act in California in the intoxicated state." 46 The Court resolved this dilemma in favor of application of the California rule making the bar owner civilly liable. The method adopted by the Court to do this is to measure the "comparative impairment" 47 of the policies of the two states if the law of the other state were applied. The Court found that California's interest in protecting its residents would be very seriously impaired if California law did not reach out-of-state tavern keepers who, like defendant, regularly and purposefully sell intoxicating beverages to

\footnotetext{
Neumeier New York might apply New York law in a spirit of altruism, Ontario should not apply New York law if New York would not)

45. 16 Cal. 3d 313, 546 P.2d 719, 128 Cal. Rptr. 215, cert. denied, 429 U.S. 859 (1976).

46. $16 \mathrm{Cal}$. $3 \mathrm{~d}$ at $322,546 \mathrm{P} .2 \mathrm{~d}$ at $725,128 \mathrm{Cal}$. Rptr. at 221 . There is no empirical evidence that dramshop laws deter bartenders from serving excessive amounts of alcoholic beverages to driving patrons. Nelson \& Roethe, Driving under the Influence of Alcohol: A Wisconsin Study, 1970 WIs. L. Rev. 495, 510. If the California policy were simply to provide an additional and probably solvent defendant for the victim to sue, comparative impairment analysis should require the Court to determine whether the driver's assets, including insurance coverage, were sufficient to compensate plaintiff without looking to the Nevada club. See text accompanying notes 53-55 infra.

47. See Baxter, Choice of Law and the Federal System, 16 Stan. L. Rev. 1, 18 (1963); Horowitz, supra note 39 , at $752-53$.
} 
California residents in places and under conditions in which it is reasonably certain these residents will return to California and act in California while still intoxicated. The Court found, however, that Nevada's interest in protecting its tavern keepers would not be significantly impaired when, as in the instant case, liability is imposed only on tavern keepers who actively solicit California business. Moreover, the Court reasoned, since the act of selling alcoholic beverages to obviously intoxicated persons is already a crime in Nevada, the application of California's rule of civil liability will not impose an entirely new duty on Nevada bar owners requiring the ability to distinguish between California residents and other patrons.

I do not find this reasoning cogent. The most obvious difficulty is that the Court failed to note that the Nevada statute imposing criminal sanctions for serving liquor to inebriated persons had been repealed after the accident but almost three years before the opinion. ${ }^{48}$ Unless the Court is issuing a one-trip ticket, it is imposing on Nevada bartenders a new duty. The Court suggests that relatively few Nevada tavern keepers will be affected. In the absence of empirical data, is there any reason not to believe that relatively few Californians injured in California would be affected if the decision had gone the other way ${ }^{49}$ One can certainly imagine a Nevada court applying what purports to be exactly the same method of analysis and coming to the opposite conclusion. ${ }^{50}$ Unless supplemented by specific objective criteria, "comparative impairment" is unlikely to be a method that is cogent, feasible to administer, and predictable.

\section{B. Objective Bases for a "Comparative Impairment" Method}

What are such specific objective criteria? A convincing argument can be made that a state's policies will be unimpaired when its law is not applied if the law in issue does not in fact advance the policies on which it purports to be based. ${ }^{51}$ For example, it can be contended that a guest statute does not prevent collusive suits or shield hosts from ungrateful guests. In the absence of clear empirical verification, however, such a route is very hazardous. It should be traveled, if at all, with great caution. ${ }^{52}$

Another objective basis for comparing policy impairment is to determine whether the policies advanced by the laws of one state are eliminated or

48. 1973 Nev. Stats. 1062 , c. $604, \S 8$, S.B. 359. Effective July 1, 1973. Nev. Rev. Stat. $\S 218.530(1975)$.

49. See Note, After Hurtado and Bernhard: Interest Analysis and the Search for a Consistent Theory for Choice-of-Law Cases, 29 STAN. L. REv. 127, 146 (1976).

50. Id.; Note, Choice of Law for True Conflicts, 65 CAL. L. REv. 290, 303 (1977).

51. See Horowitz, supra note 39, at 756-58; [L.] McDougal, Choice of Law: Prologue to a Viable Interest-Analysis Theory, 51 TUL. L. REv. 207, 213 (1977).

52. See Trautman, supra note 22 , at 15 . 
greatly attenuated by the actual facts of the case at bar. ${ }^{53}$ For example, even if one concedes that guest statutes prevent collusion, if the guest is killed in the crash, he cannot be a party to collusion. ${ }^{54}$ Or if the place of injury has a hypothetical interest in providing recovery in order to insure the payment of local medical creditors, this interest disappears if the medical creditors are paid or if there are sufficient funds to pay them without resort to the tortfeasor or his liability insurer. ${ }^{55}$

Another cogent basis for comparative impairment analysis is present if the state with the opposing rule has, since the occurrence in issue, changed its rule for future cases to accord with the rule of the other state. ${ }^{56}$ This is most likely to occur if the changed rule was objectively anachronistic. A rule is objectively anachronistic when over recent time many states with the rule have abandoned it and none or very few have adopted it. ${ }^{57}$ This is distinguished from "anachronism" as a subjective epithet attached to any rule that does not accord with the speaker's social and political philosophy. I have contended that this kind of objective anachronism is a satisfactory basis for resolving true conflicts. $^{58}$ The fact that the other state has joined the clearly discernible movement simply adds cogency to the "anachronism" argument.

\section{IV \\ Bernhard as a Nexus Problem}

One of the difficulties with Bernhard is that it raises a very tough question for which the new method of conflicts analysis has no ready answer: what contact, if any, other than residence of the plaintiff, should the forum have before applying its own law in favor of the plaintiff? In Bernhard, should a

53. See Horowitz, supra note 39 , at 753-54.

54. See Trautman, supra note 22 , at 11 .

55. But see Milkovich v. Saari, 295 Minn. 155, 203 N.W.2d 408 (1973) (place of injury gets interest from likelihood of medical bills whether or not they have been paid in case at bar).

56. For cases in which the court notes a change in the law of one state and applies the law of the other state, see, e.g., Rosenthal v. Warren, 374 F. Supp. 522 (S.D.N.Y. 1974) (charitable immunity); Wallis v. Mrs. Smith's Pie Co., 550 S.W.2d 453 (Ark. 1977) (contributory negligence); State ex rel. Broglin v. Nangle, 510 S.W.2d 699 (Mo. 1974) (limit on wrongful death damages) (change in forum law); Labree v. Major, 111 R.I. 657, 306 A.2d 808 (1973) (gross negligence for guest's recovery); Gagne v. Berry, 112 N.H. 125, 290 A.2d 624 (1972) (same); Central Mut. Ins. Co. v. H.O., Inc., 63 Wis. 2d 54, 216 N.W.2d 239 (1974) (statute of limitations). But see Hanley v. Tribune Pub. Co., 527 F.2d 68 (9th Cir. 1975). In Hanley, the choice was between the libel rules of California (newspaper incorporated and published) and Nevada (plaintiff's domicile where some papers circulated). California law required the plaintiff to allege special damages unless retraction of the libel was demanded and not forthcoming. At the time of publication, Nevada law did not require that special damages be pleaded. The court applied Nevada law as of the time of publication even though the Nevada rule had since been changed to conform to the California law.

57. This definition of "objective anachronism" might be enlarged to include an aberrant plaintiff-favoring rule. A plaintiff-favoring rule is "aberrant" if adopted by one or very few states and sufficient time has passed to make it clear that more states are unlikely to adopt the rule.

58. See R. Weintrau B, supra note 4 , at 206-07. 
Nevada tavern keeper be held civilly liable under California law for conduct in Nevada that under Nevada law would have been immune from civil liability?

There are several other recent cases that raise the question of whether the plaintiff's state has sufficient nexus with the defendant or with the defendant's course of conduct to make it fair and reasonable to hold the defendant liable under the plaintiff-favoring rule of the plaintiff's state. In Rosenthal $v$. Warren, ${ }^{59}$ a New York resident was operated on in a Boston hospital by a world-renowned Boston surgeon. The plaintiff died after the surgery and a wrongful death action was brought in New York against the doctor and the hospital. At the time of the death, Massachusetts limited recovery to $\$ 50,000$, but New York had no limit. A majority of the court held that the Massachusetts limit was not applicable and justified the result in part on the basis of the interstate nature of the transaction-the Massachusetts hospital and the famous surgeon treated patients from all over the world.

Schwartz $v$. Consolidated Freightways Corporation ${ }^{60}$ raises the nexus problem in an extreme form. The plaintiff, a Minnesota resident, was driving a truck in Indiana when he was involved in a three-truck collision. Both of the other trucks were garaged and maintained in Ohio. The plaintiff went back to Minnesota and there sued the two corporations that owned the two trucks with which he had collided in Indiana. The only connection between the defendants and Minnesota that the court mentions is stated as follows: " $[B]$ oth defendant corporations, although foreign to Minnesota, are licensed to do business in this state, and presumably exercise this privilege." ${ }^{11}$ The court nevertheless held that the Minnesota comparative negligence rule was applicable rather than the Indiana contributory negligence rule, which would have completely barred recovery by the Minnesota plaintiff.

It is interesting to compare the plaintiff-favoring results of cases like Bernhard, Rosenthal, and Schwartz ${ }^{62}$ with Maguire v. Exeter E Hampton Electric

59. 475 F.2d 438 (2d Cir.), cert. denied, 414 U.S. 856 (1973), on remand, 374 F. Supp. 522 (S.D.N.Y. 1974) (defense based on Massachusetts charitable immunity rule stricken).

60. 300 Minn. 487, 221 N.W.2d 665, cert. denied sub nom. Spector Freight System, Inc. v. Schwartz, 425 U.S. 959 (1976).

61. 300 Minn. at 492,221 N.W.2d at 668.

62. See, e.g., Foster v. Maldonado, 315 F. Supp. 1179 (D.N.J.), leave to appeal denied, 433 F.2d 348 (3d Cir. 1970) (Pennsylvania resident killed in New Jersey in collision with New Jersey resident-more generous Pennsylvania measure of recovery applied); Wallis v. Mrs. Smith's Pie Co., 550 S.W.2d 453 (Ark. 1977) (Arkansas plaintiff collides in Missouri with truck owned by Pennsylvania defendant-Arkansas comparative negligence rule applied); Tjepkema v. Kenney, 31 App. Div. 2d 908, 298 N.Y.S.2d 175, motion to appeal dism'd, 24 N.Y.2d 942, 250 N.E.2d 68, 302 N.Y.S.2d 580 (1969) (New Yorker killed in Missouri collision with Missouri driver-Missouri statutory limit on damages not applied); MacKendrick v. Newport News Shipbuilding \& Dry Dock Co., 59 Misc. 2d 994, 302 N.Y.S.2d 124 (Sup. Ct. 1969) (New Yorker sent by New York employer to work on equipment of Virginia defendant in Virginia killed on job by defendant's alleged negligence-Virginia limit on recovery not applied) (subsequently judgment was rendered for the defendant on a finding of no negligence, 40 App. Div. 2d 798, 338 N.Y.S.2d 41 (1972). 
Company $y^{63}$-a case in which the defendant's state got to appraise the nexus problem. In Maguire, a Maine resident who was an employee of a New Hampshire firm, was killed in the course of his employment in New Hampshire. Under New Hampshire law at the time, the limit on recovery was $\$ 20,000$, but under the law of Maine there was no limit on recovery. The New Hampshire court found that the New Hampshire limit on recovery was applicable despite the fact that the New Hampshire court had abandoned the place-of-wrong rule; that to resolve a real conflict it would apply the law that it deemed the "better" rule; and that in this case it found that the New Hampshire rule was not the "better" law, but, on the contrary, that its "limitation death statute lies in the backwater of the modern stream." 64 What was the reason for this result? The court stated: "What this case comes down to is that the only relationship or contact with Maine is the fact that the decedent was a resident of Maine. Surely this is not enough, standing alone, to warrant the application of Maine law to the issue of damages." 65

Is there any reason why, as a limit on interest analysis, the plaintiff's state should have some reasonable nexus with the defendant or the defendant's course of conduct before its law is applied to the defendant, or is this requirement just an atavistic retreat to territorial dogma? ${ }^{66}$ In extreme cases the defendant may be able to make a realistic unfair surprise argument; that he would have acted differently or obtained different insurance if he had any reason to take plaintiff's law into account. This surprise argument, however, is not likely to be cogent when addressed to unintentional torts with all contacts in the United States. The unintentional nature of the tort makes it unlikely that the defendant shaped his conduct to conform with a tort rule, and standards of recovery between states are sufficiently similar, so that it is unlikely that the defendant has procured $\$ 5,000$ worth of liability insurance rather than $\$ 500,000$ in reliance on the defendant-favoring rule of his home state. Nor is it realistic to speak of the insurer as being surprised. The loss is just grist for its actuarial mill. ${ }^{67}$

Even in cases in which a nexus requirement cannot be tied to a realistic unfair surprise argument, however, it is likely that the defendant will perceive his treatment as unfair if the plaintiff's state applies its law to him for no other reason than that his victim is a resident of that state. ${ }^{68}$ And it is not

63. 114 N.H. 589, 325 A.2d 778 (1974).

64. 114 N.H. at 592,325 A.2d at 780 .

65. Id.

66. See Sedler, Weintraub's Commentary on the Conflict of Laws: The Chapter on Torts, 57 IowA L. REv. 1229, 1236 (1972) ("territorial hang-up"); Sedler, The Truly Disinterested Forum in the Conflict of Laws: Ratliff v. Cooper Laboratories, 25 S.C. L. REv. 185, 188 n.19 (1973) (application of forum law justified whenever nominal defendant's insurer does business in the forum).

67. See R. Weintraus, supra note 4, at 205-06 (explaining why the actuarial process makes it "nonsense" to talk of surprising the automobile liability insurer).

68. See Reese, supra note 30, at 330; von Mehren, Recent Trends in Choice-of-Law Methodology, 60 Cornell L. Rev. 927, 961 (1975). 
likely that the defendant's state would resolve the choice-of-law problem in that manner. Reasonable contacts between the plaintiff's state and the defendant, or at least the defendant's ability to foresee that in many, not just extraordinary, cases his conduct will have an effect in the plaintiff's state-these are probably necessary before the defendant will perceive his treatment under plaintiff's law as fair. ${ }^{69}$ This perception of fairness is important to any choice-of-law methodology.

\section{V \\ Proposed Rules for Tort Cases}

The easiest choice-of-law rule to apply is one that is result oriented rather than territorially oriented. There may be reasonable debate concerning which state has the "most significant relationship"70 or will have its policies least impaired, but not about which rule is most favorable to the plaintiff. If there is, let the plaintiff choose. The question is whether there is any sound policy basis for a plaintiff-favoring conflicts rule in torts. There is because recovery, with loss-distribution through the tortfeasor's liability insurance, represents the most pervasive aspect of tort developments in this country over the past several decades. ${ }^{71}$ It makes sense to have a choice-of-law rule in accord with widely shared and clearly discernible trends in the domestic laws whose conflicts we are trying to resolve. But this result-orientation should be only a presumption. The elements that will rebut this presumption in a particular case should be clearly stated. Objective anachronism ${ }^{72}$ is one obvious rebutting element. It is rare today that a plaintiff-favoring tort rule will be anachronistic, but perhaps, for example, actions for alienation of affections qualify. ${ }^{73}$ It may be that soon, with the growth of first-party no-fault insurance, a wide range of actions against alleged tortfeasors for personal injury will be consigned to the dustbin of history. Another rebutting element is that imposition of liability under a plaintiff-favoring rule must be under circumstances that will be perceived as fair in the light of the defendant's activities. These are the conclusions that I draw from the prior sections of this article. The following choice-of-law rules for torts are intended to incorporate these concepts.

1. "FALSE CONFLICT" CASES: IF, IN THE LIGHT OF ITS CONTACTS WITH THE PARTIES OR THE TRANSACTION, ONLY ONE STATE WILL HAVE THE POLICIES UNDERLYING ITS TORT RULE

69. In extreme cases, application of the forum's law without contacts with the defendant or the defendant's course of conduct may violate due process. See Home Ins. Co. v. Dick, 281 U.S. 397 (1930); R. Weintraub, supra note 4 at 384-86 (Dick cannot be explained in terms of unfair surprise); Kirgis, The Roles of Due Process and Full Faith and Credit in Choice of Law, 62 CoRnell L. Rev. 94, 97, 104, 135-36 (1976).

70. Restatement (Second) of Conflict of Laws $\$ 145$ (1971).

71. See Reese, supra note 30 , at 333. But of. Cavers, supra note ${ }^{*}$ at 122.

72. See text accompanying notes 56.57 supra.

73. See W. Prosser, Handbook of the Law of Torts 887-88 (4th ed. 1971). 
ADVANCED, APPLY THE LAW OF THAT STATE.

2. "TRUE CONFLICT" CASES: IF TWO OR MORE STATES HAVING CONTACTS WITH THE PARTIES OR THE TRANSACTION WILL HAVE THE POLICIES UNDERLYING THEIR DIFFERENT TORT RULES ADVANCED, APPLY THE LAW THAT WILL FAVOR THE PLAINTIFF UNLESS ONE OR BOTH OF THE FOLLOWING FACTORS IS PRESENT:

a. THAT LAW IS ANACHRONISTIC.

b. THE STATE WITH THAT LAW DOES NOT HAVE SUFFICIENT CONTACT WITH THE DEFENDANT OR THE DEFENDANT'S ACTUAL OR INTENDED COURSE OF CONDUCT TO MAKE APPLICATION OF ITS LAW REASONABLE.

3. "NO INTEREST" CASES: IF NONE OF THE STATES HAVING CONTACTS WITH THE PARTIES OR THE TRANSACTION WILL HAVE THE POLICIES UNDERLYING ITS TORT RULE ADVANCED, APPLY THE LAW THAT WILL FAVOR THE PLAINTIFF UNLESS ONE OR BOTH OF THE FOLLOWING FACTORS IS PRESENT:

a. THAT LAW IS ANACHRONISTIC.

b. THE STATE WITH THAT LAW DOES NOT HAVE SUFFICIENT CONTACT WITH THE DEFENDANT OR THE DEFENDANT'S ACTUAL OR INTENDED COURSE OF CONDUCT TO MAKE APPLICATION OF ITS LAW REASONABLE. ${ }^{74}$

I harbor no delusion that even if these rules were widely adopted, torts conflicts cases would overnight become ministerial child's play-nor would I wish to foster mechanical and unthinking decision making. I do believe that these rules point the court to the right questions and are feasible to administer. It would be possible, but not easy, to argue on both sides of Neumeier and Bernhard under these rules. I would decide Neumeier under my rule 3 and reach the result opposite that reached by the New York Court of Appeals. But if that Court were truly convinced that Ontario wished to deter ingratitude of Ontario guests, even dead ones, and that New York had no policy of making its drivers responsible cost distributors no matter whom they injured, then the same result in fact reached could be reached under rule 1 . Under rule 2, I would reach the same result as was reached in Bernhard. But it could be argued that California lacked sufficient nexus with defendant to make that result reasonable. With the crash site approximately sixty miles from the club, however, that argument is difficult to make with a straight face. No, the results to be reached under these rules are not ineluctable-just, I hope, sensible and with clearly articulated bases for decision.

74. It is very unlikely that lack of nexus with defendant will be a major factor in the nointerest case. The classic example of such a case is one in which the defendant's domicile has the law favoring the plaintiff. 